Carine Riou

University of Paris 1 Pantheon-Sorbonne

\title{
THE IMPLEMENTATION IN FRANCE OF COUNCIL DIRECTIVE 2011/85/EU ON REQUIREMENTS FOR BUDGETARY FRAMEWORKS OF THE MEMBER STATES
}

Council Directive 2011/85/EU on requirements for budgetary frameworks of the Member States fits into the process of strengthening European governance aimed at ensuring economic and financial stability of the European Union. The new rules governing the surveillance of national fiscal and economic policies have been adopted in the "Six Pack"1 along with the "Two Pack" and the Treaty on Stability, Coordination and Governance in the Economic and Monetary Union (TSCG) ${ }^{3}$.

The Directive states the minimum requirements for budgetary frameworks of the Member States. The budgetary framework is defined as "the set of arrangements, procedures, rules and institutions that underlie the conduct of budgetary policies of general government". Among the components of this framework, the Directive distinguishes between the accounting and the statistics, the forecasts, the numerical fiscal rules, the medium-term budgetary frameworks as well as the transparency and the consistency of the national financial public system as a whole. The aim of the Directive is the establishment of a budgetary framework that is able to respect the commitments subscribed by the states to the European Union, and in particular Protocol No. 12 on excessive deficit procedure ${ }^{4}$. This requires rapid consolidation of public finances in a number of states, including France. The strengthening of public financial systems is hereinafter examined.

Preventing a new crisis within the Union requires the respect of European criteria of deficit and debt. The trajectory to return to a balanced budget fits into the framework of multiannual fiscal planning reinforced by Directive 2011/85/

\footnotetext{
1 The "Six Pack" includes six legislative acts which entered into force on 13 December 2011, five regulations and Directive 2011/85/EU of 8 November 2011, on requirements for budgetary frameworks of the Member States.

2 The "Two Pack" includes two regulations entered into force on 30 May 2013.

3 The treaty on stability, coordination and governance in the economic and monetary union was signed by the Heads of State and Government on 2 March 2012. It entered into force on 1 January 2013.

4 Protocol No.12 on the excessive deficit procedure annexed to the treaty on European Union and to the treaty on the functioning of the European Union.
} 
UE. To be "realised", this planning must be based on a number of "preconditions" that guarantee the completeness and the reliability of financial information of the entire public financial system.

France had recognised the need to modernise its budgetary framework before the issuing of Directive 2011/85/EU. The modernisation of its framework, even though not perfect, was consistent with the requirements of the Directive's multiannual fiscal planning when it was introduced in 2008 (I). The fiscal planning relies on budgetary and accounting rules that have yet to be brought into compliance with all of the provisions of the Directive (II).

\section{A strengthened multiannual fiscal planning}

Chapter V of Council Directive 2011/85/UE, imposes the introduction by the Member States of a credible, effective medium-term budgetary framework providing for a planning horizon of at least three years together with the requirement to include a number of pieces of information. If a similar system already existed in France (A), it was completed by the Organic Law of 17 December 2012, which implements provisions of the Directive (B).

\subsection{The initial system: the planning law of public finances introduced by the constitutional review of 23 July 2008}

The multiannual financial framework of France is formalised by the planning law of public finances. It was introduced in Article 34 of the Constitution by a review of 23 July $2008^{5}$.

The planning law of public finances is the main tool for managing the whole public financial system. Indeed, the perimeter of law of planning integrates central governments, local governments and social security organisations. In this sense, it is consistent with European commitments ${ }^{6}$. However, it must be explained that the laws of planning are not binding. They are not financial laws but ordinary ones. Adopted by Parliament, their introduction in the budgetary process has nevertheless given a solemn character to the commitments of France.

On the basis of Article 34 of the Constitution, three planning laws of public finances have been adopted.

Constitutional law No. 2008-724 of modernizing of the Fifth Republic's institutions. A new paragraph has been written: "The multiannual guidelines for public finances are defined by the planning laws. They fit in the goal of balance of general government's accounts." to the Treaty on the Functioning of the European Union. 
The first planning law was adopted in February 2009 for the period 2009-20117. The fiscal path defined "was rendered null and void by the economic and financial crisis, which led to a rapid and marked deterioration of public finances"8.

The second planning law, adopted on 28 December 2010, covers the period 2011-2014 . It determines the evolution of the funding requirements balance and of government debt. It sets a target of increasing public spending for all general governments and for each sub-sector. However, it should be noted that due to legal considerations, the principle of self-administration of local authorities defined by Article 72 of the Constitution ${ }^{10}$, and technical considerations, the control of three sub-sectors,- state, local authorities and social security organisations - must be distinguished. "Numerical fiscal rules" ${ }^{11}$, in the sense of Directive 2011/85/EU, are stated. The state spending is stabilised in value, excluding debt burden and pensions of civil servants. Limits by missions of the general budget are also defined. The financial contributions of the state to local governments are stabilised in value. The evolution of expenditures of compulsory basic social security plans, as well as that relating to health insurance, are supervised ${ }^{12}$. A minimum amount of new measures relating to compulsory levies is also defined. Finally, governance rules are specified.

The impact of the planning law of public finances for the period 2011-2014 can only be the object of a partial evaluation, because the parliamentary elections in June 2012 have brought to the government a new political majority. However, in accordance with the planning law, a document mentioning the results of this planning law was sent by the Government to the Senate Committee on Finance, on 10 July $2012^{13}$. Also according to data taken by the national institute of statistics and economics studies and the report of the Court of Auditors on the situation and the prospects of public finances 2012, it is possible to consider the fiscal planning for 2011-2014 was generally respected the first year. The public deficit is lower than that provided by the planning law, $5,3 \%$ of gross domestic product (GDP) instead of $6 \%$ GDP. The Court of Auditors concludes that "the path of fiscal consolidation required

$7 \quad$ Law No. 2009-135 of 9 February 2009 of planning of public finances for the years 2009-2012.

8 Fr. "a été rendue caduque par la crise économique et financière, qui a conduit à une dégradation rapide et marquée des finances publiques". Explanatory memorandum of the planning bill of public finances for the years 2011-2014.

9 Law No. 2010-1645 of 28 December 2010 of planning of public finances for the years 2011-2014.

10 The objectives of the planning law have a « programmatic " scope and they are therefore devoid of normativity. See also Cour des comptes, Rapport sur la situation et les perspectives des finances publiques, juillet 2012, p. 192.

11 Article 5 of Directive 2011/85/EU.

12 A mechanism of monitoring and alerting is also associated with the national goal of health insurance expenses in accordance with Article 6 of Directive 2011/85/EU.

13 Article 15 of the planning law for the years 2011 to 2014: "The Government must prepare and submit annually to Parliament, before the policy debate of public finances, a report on the implementation of this law". Fr. "Le Gouvernement établit et transmet chaque année au Parlement, avant le débat d'orientation des finances publiques, un bilan de la mise en oeuvre de la présente loi". 
by planning law has been observed, as well as standards for public spending and revenue" 14 .

The third law of public finances planning was adopted on 31 December 2012, for the years 2012 to $2017^{15}$. This instrument initially defined from 2009 has been completed.

\subsection{The current system: the planning law of public finances enriched by the Organic Law of 17 December 2012}

The planning laws of public finances have been greatly enriched by the introduction to the national law of a number of budgetary provisions of TSCG by the Organic Law of 17 December 2012, on the planning and the governance of public finances ${ }^{16}$. Thus, if the main object of the Organic Law is the implementation of Article $3 \mathrm{TSCG}^{17}$, which provided an objective of general government's structural balance, "in the alternative, the organic legislator is invited to draw some consequences of the reform of the Stability and Growth Pact occurred in 2011, as the "Six Pack". In particular, the draft organic law tends to complete implementation of the Directive of 8 November 2011"18.

Chapter 1 of the Organic Law completes the initial instrument in accordance with the commitments of France. Now, "the law sets the planning medium-term objective of public governments (...). It determines (...) the trajectories of structural and effective annual balances (...) as well as the public debt evolution. (...) The planning law of public finances provides a breakdown of annual effective balances by sub-sector." ${ }^{\prime 19}$ More generally, the first five articles of the Organic Law specify the content of planning laws. They take again the largest share of notified provisions in the previous planning laws, combined with new obligations of Directive 2011/85/ EU. For example, Article 5 provides the publication of a report attached to the planning law including in particular "the financial projections at unchanged policies (...) and the description of policies proposed to achieve the medium-term budgetary

14 Fr. "la trajectoire de redressement des finances publiques prévue par la loi de programmation a été respectée, de même que les normes budgétaires applicables aux dépenses et aux recettes publiques". Cour des comptes, Rapport sur la situation et les perspectives des finances publiques, juillet 2012, p. 47.

15 Law No. 2012 - 1558 of 31 December 2012 of planning of public finances for the years 2012-2017.

16 Organic Law No. 2012-1403 of 17 December 2012 on the planning and the governance of public finances.

17 TSCG ratified by Law No. 2012 - 1171 of 22 October 2012.

18 Fr. "à titre subsidiaire, le législateur organique est invité à tirer certaines conséquences de la réforme du Pacte de stabilité et de croissance intervenue en 2011, sous la forme du "Six Pack". En particulier, le projet de loi organique tend à parachever la transposition de la directive du 8 novembre 2011". Assemblée nationale, Rapport $\mathrm{n}^{\circ} 244$ fait au nom de la commission spéciale chargée d'examiner le projet de loi organique ( $\left.n^{\circ} 198\right)$, après engagement de la procédure accélérée, relative à la programmation et à la gouvernance des finances publiques, octobre 2012, pp 23-24.

19 Fr. "la loi de programmation fixe l'objectif à moyen terme des administrations publiques (...). Elle détermine (...) les trajectoires des soldes structurels et effectifs annuels (...) ainsi que l'évolution de la dette publique. (...) La loi de programmation des finances publiques détermine l'effort structurel. (...) La loi de programmation des finances publiques présente la décomposition des soldes effectifs annuels par sous-secteur". Article 1 of Organic Law No. 2012-1403 of 17 December 2012 on the planning and the governance of public finances. 
objective with respect to these projections"20, in accordance with Article 9 of the Directive.

On the basis of article 34 of the Constitution, an enriched planning law has been adopted. Broadly, the effort to reduce the public deficit in planning is continued and completed by the reduction in public spending objectives associated with a tax effort of nearly one percentage point of GDP. New "conduct rules"21 are introduced, including the transmission of the Stability Program to Parliament. The procedure associated to the correction mechanism prescribed by TSCG, which is activated if there is a deviation from the originally described fiscal path, is defined. The participation of the High Council of Public Finances, an independent body within the meaning of Directive 2011/85/UE, strengthens the respect of Chapter IV, "numerical fiscal rules", and in particular the provisions of Article $6^{22}$.

It is possible to make a number of observations on the implementation of the planning law of 31 December 2012 (the details of current programming are presented in Table No 1). It projected a deficit equal to 3\% GDP in 2013. In agreement with the European institutions, this aim has been postponed to 2015. However, the return to structural balance has been kept in 2016. The results for 2013, announcing a public deficit of 4,1\% GDP and a structural deficit of 2,6\% GDP, will have to be confirmed at the end of March 2014 23 . The Court of Auditors notes that "despite a considerable structural effort, the actual deficit and the structural deficit in 2013, remained at levels significantly higher than those recorded in the planning law and in the initial financial law for 2013"24. The Court also mentioned "the uncertain realisation" 25 of the goal of deficit reduction in 2014. In conclusion, the Court notes "a delay relative to the path of planning law"26. A review of the planning law of public finances for the years 2012 to 2017 has been announced for autumn 2014.

\footnotetext{
20 Fr. "les projections de finances publiques à politiques inchangées (...) et la description des politiques envisagées pour réaliser l'objectif à moyen terme au regard de ces projections".

21 Fr. "règles de comportement". G Gaubert “Loi de programmation des finances publiques et intégration budgétaire" RFFP n`122, avril 2013 p. 149

22 See below.

23 Data of economic, social and financial report annexed to the financial bill for 2014.

24 Fr. "malgré un effort structurel considérable, le déficit effectif et le déficit structurel sont restés en 2013 à des niveaux nettement supérieurs à ceux inscrits dans la loi de programmation et la loi de finances initiale pour 2013". Cour des comptes, Rapport public annuel 2014, février 2014, p. 26. The Court of Auditors states that forecasts of both laws are identical.

25 Fr. "la réalisation incertaine". Cour des comptes, op. cit., p. 32.

26 Fr. "un retard par rapport à la trajectoire de la loi de programmation". Cour des comptes, op. cit., p. 46.
} 
Table No 1: Budgetary planning 2012-2017

\begin{tabular}{|c|c|c|c|c|c|c|}
\hline & $\mathbf{2 0 1 2}$ & $\mathbf{2 0 1 3}$ & $\mathbf{2 0 1 4}$ & $\mathbf{2 0 1 5}$ & $\mathbf{2 0 1 6}$ & $\mathbf{2 0 1 7}$ \\
\hline Public actual balance $(1+2+3)$ & $-4,5$ & $-3,0$ & $-2,2$ & $-1,3$ & $-0,6$ & $-0,3$ \\
\hline Cyclical balance (1) & $-0,8$ & $-1,2$ & $-1,0$ & $-0,8$ & $-0,5$ & $-0,3$ \\
\hline Limited and temporary measures (2) & $-0,1$ & $-0,2$ & $-0,1$ & 0,0 & 0,0 & 0,0 \\
\hline Structural balance (in points of potential GDP) (3) & $-3,6$ & $-1,6$ & $-1,1$ & $-0,5$ & 0,0 & 0,0 \\
\hline
\end{tabular}

Source: Law No. 2012 - 1558 of 31 December 2012 of planning of public finances for the years 2012-2017.

The content of the fiscal planning of France appears broadly consistent with the requirements prescribed by Directive 2011/85/EU, outside nevertheless of an assessment of the impact of public policies on the sustainability of public finances ${ }^{27}$. More problematic is the respect of the fiscal path. One reason is the reviewing of growth prospects during the year. In February 2014, the National Institute of Statistics and Economics Studies estimated economic growth for 2013 at $0,3 \%$. It was estimated at $1,75 \%$ in May 2012 and at $0,1 \%$ in April 2013. If this exercise of forecast is by definition random, comparison of the data used by the Government to those of international institutions ${ }^{28}$ leads to a need for more "prudent" fiscal planning, in accordance with Article 4 of the Directive ${ }^{29}$. In this instance, we have to refer to the budgetary and accounting rules which govern planning.

\section{A budgetary framework partially reliable}

The respect of the criteria stated in Article 1 of Protocol No. 12, completed by TSCG, requires the prior capacity to have complete and reliable public financial information. Besides, the control of the entire public financial system obliges the coordination of each sub-sector. If the construction of the reliability of budgetary and accounting data is well underway in France (A), the lack of integration of each of the public bodies could decelerate the long-awaited results of Directive 2011/85/EU implementation (B).

\subsection{The improvement of accuracy of public financial information}

Two components of the budgetary framework are particularly concerned by the reforms in terms of budgetary data reliability, the macroeconomic forecasts on which the budget is built as well as the accounting systems and statistical information.

27 Article 9 of Directive 2011/85/EU.

28 Most data are available in "Les indicateurs de conjoncture hebdomadaire" on the website of the Bank of France.

29 "Budgetary planning shall be based on the most likely macrofiscal scenario or on a more prudent scenario." 
Under the terms of the Directive, "biased and unrealistic macroeconomic and budgetary forecasts can considerably hamper the effectiveness of fiscal planning and consequently impair commitments to budgetary discipline". Under Article 4, "Member States shall ensure that fiscal planning bases on realistic macroeconomic and budgetary forecasts using the most up-to-date information". Member States shall specify who is responsible for establishing macroeconomic and budgetary data, publish them, set out the methodology underpinning their production and proceed to an ex post evaluation. The economic, social and financial report annexed to the draft financial law contains such information. Article 6, realises the recommendations made in the production of forecasts citing "the effective and timely monitoring of compliance with the rules based on reliable and independent analysis carried out by independent bodies or bodies endowed with functional autonomy vis-à-vis the fiscal authorities of the Member States". The opinion of the European Central Bank on the economic governance reform also provides that "the creation of independent fiscal councils should appear as a priority in the Directive" ${ }^{30}$. Their implementation is further reinforced by Article 3 of $\mathrm{TSCG}^{31}$ and by the regulation of the "Two Pack" 32 on common provisions for monitoring and assessing draft budgetary plans and ensuring the correction of excessive deficits in Member States of the euro area.

The interim progress report on the implementation of the Directive ${ }^{33}$ could not account for the creation of the High Council of Public Finances by the Organic Law on the planning and the governance of public finances of 17 December 2012. In a report in public finances in the European Union, the Commission however noted that "the Court of Auditors is independent and performs the tasks of an independent fiscal committee, with the exception of macroeconomics forecasts" 34 . Now, the High Council of public finances advises on macroeconomic assumptions underlying financial bills, social security financing bills, planning bills of public finances and Stability Programs. In addition, the High Council appreciates the consistency of the structural balance path with the financial commitments of France. In accordance with the requirements issued by Article 4 of the Directive, an ex post and published evaluation of macroeconomic and budgeting forecasts shall be realised by the High Council. It decides on any discrepancies between the accounts of general

$30 \quad$ European Central Bank, Opinion on economic governance reform in the European Union, February 162011.

31 Article 3 of TSCG relates to the role of independent institutions in the budgetary correction mechanism. It is supplemented by the common principles for national budgetary correction mechanisms established by the European Commission in a communication of 20 June 2012.

32 Regulation EU No. 473/2013 of European Parliament and Council of 21 May 2013 on common provisions for monitoring and assessing draft budgetary plans and ensuring the correction of excessive deficits in Member States of the euro area.

33 Report from the Commission to the European Parliament and the Council, Interim Progress Report in the implementation of Council Directive 2011/85/UE on requirements for budgetary frameworks of the Member States, 14 December 2012.

34 Fr. "la Cour des comptes est indépendante et remplit les missions d'un comité budgétaire indépendant, à l'exception des prévisions macroéconomiques". Cour des comptes, Rapport sur la situation et les perspectives des finances publiques, juillet 2012, p. 187. 
governments for the previous year and the fiscal path established by planning law. The High Council identifies in particular "significant deviations" 35 that lead the Government to explain and take corrective measures.

Established by a decree of 18 February $2013^{36}$, the High Council of Public Finances pronounced four opinions. In its opinion on the financial bill and the social security financing bill for 2014, the High Council judged the growth forecast used by Government "plausible" despite a macroeconomic scenario, which "has the elements of fragility". However, it considered that the delay in respect of fiscal path defined by the planning law, and except to change the date of return to equilibrium, will lead to the implementation of the correction mechanism in spring 2014.

The systems of accounting and statistical information have also been subject to a process of reliability. The still imperfect integration of different sub-sectors pleads for the continuation of the approach on the basis of prescriptions of the Directive.

\subsection{The insufficient integration of the public financial system}

Article 12 of the Directive states that "Member States shall ensure that any measures taken to comply with Chapters II, III and IV are consistent across and comprehensive in coverage of, all sub-sectors of general government". In this context, limits at the full implementation of the Directive appear.

Accounting rules are distinct in France according to the financial sector. The social and local sectors raise more questions. In a report on local finances, the Court of Auditors notes that "despite progress over the last twenty years in the local financial information, there is still much to do" ${ }^{37}$. Thus, "the development of the budgetary situation executed during the year cannot be conveniently followed in regard to local authorities" 38 . The Court also notes that the requirements set by Article 14 of the Directive, are not satisfactory regarding information on off-balance sheet commitments ${ }^{39}$. Therefore, the Supreme Audit Institution calls "to define a path to upgrade the financial and accounting local system to answer fully the provisions of Council Directive of the European Union of 8 November 2011"40. Regarding data

Article 3 1.e) of TSCG.

Decree No. 2013-144 of 18 February 2013 r.elating to the initial establishment of the High Council of public finances.

Fr. "malgré les progrès enregistrés depuis une vingtaine d'années dans l'information financière locale, il reste beaucoup à faire". Cour des comptes, Les finances publiques locales, octobre 2013, p. 148.

Fr. "l'évolution de la situation budgétaire en cours d'exécution en cours d'année ne peut être commodément suivie en ce qui concerne les collectivités territoriales". Cour des comptes, op. cit., p. 147. See also Inspection générale des finances et Inspection générale de l'administration, La transparence financière des collectivités territoriales, décembre 2012.

Cour des comptes, op. cit., p. 146

Fr. "définir une trajectoire de mise à niveau du système financier et comptable public local afin de permettre de répondre pleinement aux dispositions prévues par la directive du Conseil de l'Union européenne du 8 novembre 2011". Cour des comptes, op. cit., p. 148. 
for social security, most are centralised, individual publications exist but no monthly aggregated situation is published ${ }^{41}$.

In respect Article 3 of the Directive, which requires that "Member States shall have in place public accounting systems comprehensively and consistently covering all sub-sectors of general government" this would require the definition of a common accounting reference or, failing that, a rapprochement of different accounting systems.

A decree of 7 November 2012, generalises the obligation to implement systems of internal control and independent audit. However, this provision does not apply to the local authorities. Concerning the implementation of Article 47-2 of the Constitution $^{42}$ by Article L 111-3-1 A of the code of financial jurisdictions, the Court of Auditors considers that it ensures a satisfactory transposition of Directive 2011/85/EU. However, it states that it "currently certifies, or cannot account for the quality because they are certified by others, only a part of the general government accounts" $"$.

The imperfect integration of the public financial system is also illustrated by the lack of coordination across the different sub-sectors. According to Article 13 of the Directive, "Members States establish an appropriate mechanism of coordination across sub-sectors of general government to provide for comprehensive and consistent coverage of all sub-sectors of general government". If information on all general governments exist, particularly in the preliminary article of the discharge bill "with an overview table depicting the structural balance and the actual balance of all general governments resulting the performance of the year to which it relates" 44 , sub-sectors are not involved in determination of the fiscal path. The Court of Auditors notes that binding fiscal rules cover only $75 \%$ of public expenditure. However, "to avoid adjustment and safety margins on only part of the public sphere, the state and the compulsory basic plans of social security, France's commitments must involve all general governments" ${ }^{45}$. Under the coordination mechanisms contained in the working document used in the preparation of the progress report of the Commission on the implementation of Directive 2011/85/EU, Article 108 of the financial law 2012, which included the publication of a report on local finances,

41 Cour des comptes, Rapport sur la situation et les perspectives des finances publiques, juillet 2012, p. 190.

42 "The general government accounts are regular and sincere. They give a true picture of their management, their assets and their financial situation. »

43 Fr. "ne certifie actuellement, ou ne peut rendre compte de la qualité parce qu'ils sont certifiés par d'autres, que d'une partie des comptes des administrations publiques". Cour des comptes, op. cit., p. 177. A report on the quality of general government accounts was published in fall 2013.

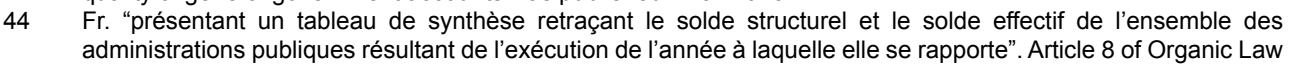
No. 2012-1403 of 17 December 2012 on the planning and the governance of public finances.

45 Fr. "pour éviter de faire porter l'ajustement et les marges de sécurité nécessaires sur une partie seulement de la sphère publique, l'État et les régimes obligatoires de base de sécurité sociale, les engagements de la France doivent impliquer toutes les administrations publiques". Cour des comptes, Rapport sur la situation et les perspectives des finances publiques, juillet 2012, p. 193. 
should be repealed by the vote on the bill of development of regional solidarity and local democracy ${ }^{46}$.

Under Article 16 of the Directive, the Commission report on the adequacy thereof shall be published before 14 December 2018. An evaluation, which will include a number of provisions similar to those of the Directive, of the compliance with TSCG by the member states must nevertheless take place in autumn 2014. However, it is clear that the governance of all public financial systems must be strengthened from now on, particularly vis-à-vis local finances. The Court of Auditors considers in this way that « a national authority could be the framework of the permanent association of local authorities at the adjustment measures, upstream to the planning laws (...) and downstream in the declination of orientations in a "pact" which would be the framework of solid and mutual commitments of the State and local authorities." ${ }^{\prime 4}$. To quote a thesis defended by Professor Michel Bouvier, "it is not only in terms of financial or fiscal techniques, but also on the institutional level, this one of the redrafting of local, national and European financial decision process, that should be decided the essential"48. This is the successfulness of public financial integration in the service of European economic governance, which is at stake.

46 Bill of development of regional solidarity and local democracy registered to the Presidency of the Senate April 10 2013. See also Inspection générale des finances et Inspection générale de l'administration, La transparence financière des collectivités territoriales, décembre 2012.

47 Fr. "une instance nationale pourrait être le cadre permanent d'association des collectivités territoriales aux mesures de redressement, tant en amont des lois de programmation de finances (...) qu'en aval dans la déclinaison des orientations au sein d'un « pacte » qui soit le cadre des engagements fermes et réciproques de l'État et des collectivités territoriales". Cour des comptes, Les finances publiques locales, octobre 2013, p. 53

48 Fr. "ce n'est pas uniquement sur le plan des techniques financières ou fiscales mais aussi sur le terrain institutionnel, celui d'une reformulation du processus de décision financière local, national et européen que devrait se jouer l'essentiel". M. Bouvier, « Autonomie financière locale et fédéralisme financier européen: sortir du quiproquo », Pouvoirs locaux, n99, décembre/janvier 2013-2014, p. 103. 
The implementation in France of Council Directive 2011/85/EU on requirements...

\section{WDROŻENIE WE FRANCJI DYREKTYWY RADY 2011/85/UE W SPRAWIE WYMOGÓW DLA RAM BUDŻETOWYCH PAŃSTW CZŁONKOWSKICH}

Dyrektywa Rady 2011/85/UE w sprawie wymogów dla ram budżetowych państw członkowskich wpisuje się w proces wzmacniania europejskiego zarządzania, mającego na celu zapewnienie ekonomicznej i finansowej stabilizacji Unii Europejskiej. Określa ona minimalne wymogi ram budżetowych. Ścieżka budżetowania staje się częścią wieloletniego planowania finansowego wzmocnionego dyrektywą 2011/85/UE. Planowanie to musi opierać się na pewnych ,przewidywaniach”, które gwarantują kompletność i rzetelność informacji finansowych całego systemu finansów publicznych.

Słowa kluczowe: programowanie, koordynacja, integracja, rzetelność

Keywords: programming, coordination, integration, reliability 